\title{
Shoppers Drug Mart or Poachers Drug Mart?
}

Published at www.cmaj.ca on Nov. 26, 2007. Revised on Jan. 4, 2008.

S hoppers Drug Mart (Pharmaprix in Quebec) is a familiar Canadian institution. Its Iooo stores dot the landscape; no pharmacy chain is larger. In many Canadian communities, the corporation's well-staffed local franchises give patients quality care.

However, in South Africa, the same corporation is potentially contributing to a public health disaster. In 2005, 2006 and twice in 2007 , it has dispatched recruiters to that country, with the mission of plucking pharmacists from a continent that has far too few for its needs. Shoppers Drug Mart promises 6-figure salaries and help to establish a brilliant career in Canada. The carrot, and the helping hand holding it, are huge.

Probably most Canadians by now have been cared for by a South African doctor, nurse or pharmacist. Migration is good for Canada because the quality of South African workers is generally excellent; but it may be catastrophic for South Africa, coinciding as it does with an AIDS epidemic, where an estimated I $9 \%$ of adults are HIV positive. Newspapers in that country report hospital patients waiting for several days just to have a prescription filled. ${ }^{1}$ In the worst-hit provinces, such as KwaZulu-Natal, hundreds of new pharmacists are needed to dispense AIDS drugs, but recently three-quarters of the slots for government pharmacists stood vacant. ${ }^{2}$

Given South Africa's extraordinary history, these difficulties have many causes. A leading cause is the relentless migration of health professionals. Medical journals in that country are full of advertisements for jobs abroad - thousands in the past few years alone. ${ }^{3}$ Any competent health care worker can find opportunities and choose to emigrate. Many do for legitimate family or career reasons, as is undeniably their right.

But the passive enticement of job advertisements stands in distinction to a different practice: active, targeted and systematic recruiting of employable pharmacists and other health professionals - better known as poaching - from South Africa's talent pool.

This form of poaching is what Shoppers Drug Mart is doing. Once or twice a year, its corporate headquarters send recruitment road shows into South Africa to woo and interview applicants. It promises candidates "guaranteed annual minimum earnings of \$100 ooo" - a huge boost compared with typical South African earnings. ${ }^{4}$ To make leaving home easy, Shoppers Drug Mart even offers up its law firm to "help ... with the immigration applications." ${ }^{4}$ The corporation's recruitment machine targets practising pharmacists, students of pharmacy and even pharmacy professors (like one of us, R.B.W.) without whom South Africa cannot replenish its pharmacist shortage.

Shoppers Drug Mart is not ashamed of this recruiting; ac- tually, it is proud of it. Its website brags: "We have a long history of helping Pharmacists from other countries start a new career in Canada." ${ }^{4}$

This behaviour is not just gauche; it is unethical. It amounts to a Canadian corporation taking advantage of South African taxpayers and the impoverished higher education system - truly foreign aid in reverse. If Shoppers Drug Mart needs workers, it should not poach them, but it should train them by subsidizing studentships at Canadian or South African schools of pharmacy. Shoppers Drug Mart pays a generous shareholder dividend and plans $\$ 400$ million of capital investment to expand its store network this year. ${ }^{5}$ It is not too poor to invest in training the pharmacy workers who are its human capital.

A thoughtful, ethical system would be a win-win solution for everyone: pharmacy schools would expand their intake through subsidized studentships, Shoppers Drug Mart would get the well-trained pharmacists it needs, and long-suffering South African patients would be more likely to get the access they need to pharmacists.

So what's stopping Shoppers Drug Mart? Studentships cost money, and the pharmacy chain operates in an industry where poaching is shamefully normalized. The Canadian Association of Chain Drug Stores does not discourage poaching, but "supports measures that will expedite the ability of international pharmacy graduates to immigrate into Canada." ${ }^{6}$ Almost certainly Shoppers Drug Mart is not the only pharmacy chain that poaches.

But as the leading chain, Shoppers Drug Mart is uniquely placed to raise the industry's subterranean ethical bar on poaching. Within this decade, countries, professional associations and the Commonwealth have all enacted codes of conduct that generally frown on poaching in the health professions. ${ }^{7}$ Those codes are morally, if not legally, binding, and socially responsible corporations ought to fall in line. Those who poach deserve to lose business. For example, the Commonwealth Health Ministers recommend that governments consider "only employing and dealing with those [private] recruitment agencies that comply with the [Commonwealth] Code."

The Shoppers Drug Mart recruitment road show went to Pretoria, Johannesburg, Durban and Cape Town. CMAJ believes that Shoppers Drug Mart should call off future poaching outings and commit to implementing a training-based solution for its worker needs - a solution that it could pioneer and that others in the chain-drugstore industry could follow. But if Shoppers Drug Mart fails to act, $C M A J$ also believes governments, hospitals and all Canadians should show solidarity for South Africa, and take their business elsewhere. 


\section{Addendum}

I) Following the early release online of this editorial on Nov. 26, 2007, a member of the CMAJ Editorial-Writing Team contacted Shoppers Drug Mart on Nov. 27 and extended an invitation to the company to submit a letter stating its position to the journal. In that discussion, Shoppers Drug Mart confirmed that the company is examining its recruiting practices, but did not advise that it cancelled any South African recruitment activities.

2) Shoppers Drug Mart appears to have continued recruiting in South Africa according to a report in The Globe and Mail, published online on December 3, 2007. ${ }^{9}$

3) As highlighted in this issue's News section, poaching of health professionals from one jurisdiction to another is widespread (CMAJ 2008;178(3):269-7I).

4) It is especially distressing when industrialized countries systematically seek to fill their human resource requirements by recruiting professionals from countries with far greater needs and shortages.

5) Solutions to address the shortage of health professionals in the nonindustrialized world go well beyond the prohibition of poaching; however, such a measure is an essential element of an integrated approach.

\section{Amir Attaran LLB DPhil}

Canada Research Chair in Law, Population Health and

Global Development Policy

University of Ottawa

Ottawa, Ont.
Roderick B. Walker PhD

Dean Elect, Faculty of Pharmacy

Rhodes University

Grahamstown, South Africa

With the Editorial-Writing Team (Paul C. Hébert MD MHSc, Matthew B. Stanbrook MD PhD, Ken Flegel MDCM MSc and Noni MacDonald MD MSc)

\section{REFERENCES}

I. Ryan M. Patients in long wait for medicine. Sunday Tribune [South Africa] 2007 Jan 7.

2. Ryan M. State pharmacies' staffing crisis. Sunday Tribune [South Africa] 2007 Jan 28.

3. Rogerson CM. Medical recruits: the temptation of South African healthcare professionals [policy paper]. Southern African Migration Project. Kingston (ON): The Project; 2007. Available: www.queensu.ca/samp/sampresources/samppublications/ (accessed 2007 Nov 23).

4. Shoppers Drug Mart. [International recruitment websites] 2007. Available: www .shoppersdrugmart.ca/english/careers/international/index.html and www.shoppers drugmart.ca/english/careers/international/africa.html and www.shoppersdrugmart.ca lenglish/careers/international/visas_permits/index.html and www.shoppersdrugmart .ca/english/careers/international/students_interns/index.html (accessed 2007 Nov 23).

5. Shoppers Drug Mart. [annual report] 2006. Available: www.shoppersdrugmart.ca lenglish/corporate_information/investor_relations/financial_information/annual _report/full_report/SDM_o6\%20English\%2ofull.pdf(accessed 2007 Nov 23).

6. Canadian Association of Chain Drug Stores. Letter to Jodi White, Public Policy Forum. 2005 June 24. Available: www.cacds.com/files/CACDS\%2oResponse $\% 20$ to $\% 20$ PPF\%20Role\%20of\%20Governments\%20June\%202005.pdf (accessed 2007 Nov 23).

7. Pagett C, Padarath A. A review of codes and protocols for the migration of health workers. Causeway, Harare (Zimbabwe): The Regional Network for Equity in Health in east and southern Africa (EQUINET); 2007. Available: www.equinetafrica .org/bibl/docs/Dis5oHRpagett.pdf (accessed 2007 Nov 23)

8. Commonwealth Health Ministers. Companion document to the Commonwealth Code of Practice for the International Recruitment of Health Workers. London: The Commonwealth Secretariat; 2003. Available: www.thecommonwealth.org /shared_asp_files/uploadedfiles/\%7B7F307830-IFA4-44A3-9EA5-9CC4055D7D4B $\% 7$ D CompanionDocument.pdf (accessed 2007 Nov 23).

9. Nolen S. Canadian firm poaches pharmacists from South Africa. The Globe and Mail. 2007 Dec 3. Available: www.shns.com/shns/scrippsnews/index.cfm?action $=$ detail\&pk=SAFRICADRUGGISTS-I2-03-07 (accessed 2008 Jan 04). 